\title{
Learning design \\ - pædagogiske og didaktiske modeller for undervisningsudvikling, kvalitetssikring og effektivisering på de videregående uddannelser
}

\section{Lillian Buus}

Ph.d., Specialkonsulent

Pædagogisk it-designer i Enheden for Læringsdesign under Forskning- og udvikling i EVU, VIA University College

\section{Mikkel Godsk}

\section{Teamleder}

Science and Technology Learning Lab,

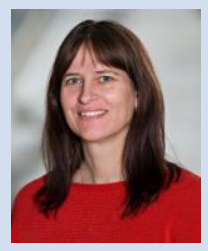
Aarhus Universitet

\section{Roland Hachmann}

\section{Ph.d.-studerende, Lektor}

Ph.d. -tuderende ved Syddansk Universitet og Lektor ved UC Syd Danmark
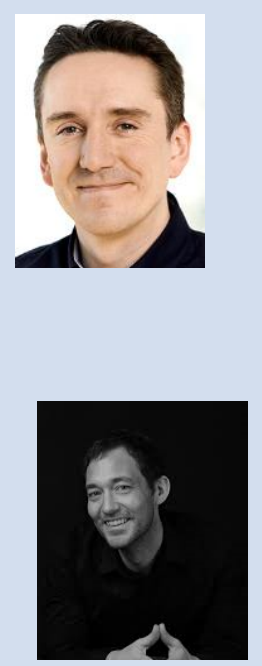


\section{Indledning}

Teknologi har for alvor vundet indpas på de videregående uddannelser i Danmark som et middel til at fremme kvaliteten, herunder til at understøtte færdighedstræning og laboratorieundervisning (se LOM nr. 12, 2014), i forbindelse med eksamen (se LOM nr. 7 og 8, 2011), til at støtte læringsmiljøet og læringsrummet (se LOM nr. 11, 2013), til feedback samt til at forbedre de traditionelle undervisningsformer i al almindelighed. Viften af anvendte teknologier er mangfoldig og alt fra video, videokonference (se LOM nr. 2, 2009), mobile teknologier og apps (se LOM nr. 10, 2013), spil, virtuelle verdener til robotter (se LOM nr. 3, 2009, nr. 9, 2012 og nr. 14, 2015) bliver anvendt til at forbedre og transformere undervisningen. Imidlertid bærer disse transformationer og teknologianvendelser ofte præg af en ad hoc-proces, hvor enten en teknologi-entusiastisk "lone ranger"-underviser ene og alene står for implementeringen af teknologien i undervisningen (Bates, 2005) eller hvor et udviklingsteam bestående af underviseren, pædagogiske konsulenter og evt. teknikere står for udviklingen af det specifikke kursus. Omend begge tilgange rummer potentialet for god brug af teknologi i undervisningen, er der samtidig risiko for, at gode erfaringer og anvendelser ikke kommer andre undervisere til gode, at omkostningerne forbundet med transformeringen overskygger de undervisningsmæssige fordele og at vigtige perspektiver bliver overset.

Som et middel til at systematisere, kvalitetssikre og effektivisere brugen af teknologi i undervisningen og understøtte undervisningsudvikling, vinder "Learning Design" og andre lignende, modelbaserede tilgange i større og større grad frem ved såvel udenlandske som danske uddannelsesinstitutioner. Learning Design er bl.a. kendetegnet ved en systematisk tilgang til undervisningsudvikling baseret på pædagogisk teori samt værktøjer, metoder og modeller til at understøtte udviklingsprocessen (Conole, 2013). Endvidere har Learning Design vist sig nyttig til at kvalitetssikre anvendelsen af teknologi i undervisningen, at få konkretiseret pædagogisk teori til håndgribelige modeller og værktøjer for undervisningsudvikling målrettet underviserne samt muliggjort genbrug og deling af god praksis (Carvalho \& Goodyear, 2014; Conole et. al., 2015; Hansen \& Dohn, 2016; Laurillard, 2012; Mor et.al., 2014). Dermed rummer tilgangen også et forretningsmæssigt potentiale, da undervisningsudvikling kan systematiseres og således også være med til at realisere teknologiens potentialer for øget kvalitet i uddannelser og effektivisering.

Dette nummer af LOM sætter særligt fokus på Learning Design og andre lignende, modelbaserede tilganges potentiale for at kvalitetssikre og effektivisere brugen af teknologi på de videregående uddannelser i Danmark gennem otte artikler, der på hver sin vis dokumenterer, hvordan Learning Design udmøntes i praksis.

- Apps i anatomiundervisningen - perspektiver for et nyt Learning Design af Solvej Videbaek, Nikolaj Bøgh, Ellen Hollands Steffensen og Søren Gullaksen, som via forskellige modeller af Learning Design forsøger at 
imødekomme de udfordringer der findes inden for den biomedicinske uddannelseskontekst og optimere læringsudbyttet ved at skabe mere effektiv undervisning understøttet at TPACK, TAM og STREAM som Learning Design-modeller.

- Applying a Learning Design methodology in the flipped classroom approach - empowering teachers to reflect and design for learning af Evangelia Triantafyllou, Lise Busk Kofoed, Hendrik Purwins og Olga Timcenko. Artiklen inddrager tilgangen Conceptual Map ind i en Flipped Classroom-undervisningstilgang med fokus på at Learning Design-tilgangen er med til at styrke opmærksomheden og guide underviserne i forhold til design af flipped learning og undervisningscyklussen i den kontekst.

- Online lektiehjælp - Udvikling af en vejledningsdidaktik med pædagogisk designforskning som metode af Jens Jørgen Hansen og Kirstin Remvig. I artiklen udvikles en didaktik inden for vejledning hvor der arbejdes $i$ snitfladerne mellem konsultativ og dialogisk vejledningsformer samt online eller offline. Fokus er på at effektivisere vejledningssituationen.

- Learning Design som systematisk alternativ til one-hit wonders implementering af educational it i de våde fag på Aarhus Universitet af Mikkel Godsk og Janne Saltoft Hansen. Artiklen illustrerer at en kobling mellem Learning Design inden for initiativer om udvikling- og undervisningstilrettelæggelse giver nogle gode muligheder for effektivt at introducere en læringsplatform, gentænke undervisningen ind i en digital kontekst og uddanne underviserne her indenfor.

- A Design-Based introduction to learning centres af Anne Kristine Petersen, Astrid Margrethe Hestbech og Peter Bukovica Gundersen. Denne artikel skitserer et projekt, hvor der er etableret centre for læring. Artiklen lægger op til at der kan arbejdes med Learning Design på flere niveauer, $\mathrm{fx}$ i forhold til at skabe effektive design for læringsmiljøer. De har også set på læringsdesign i forhold til at skabe effektive læringscentre, som kan understøtte en forbedret tilgang til uddannelse i yderområder, samt en fastholdelse af kvalificeret arbejdskraft samtidig med muligheden for efteruddannelse.

- Revitalisering af PBL $i$ videregående uddannelser gennem Learning Design af Jacob Davidsen og Ulla Konnerup. Ud over at beskrive brugen af Learning Design som en model for at gentænke et kursusforløb, så stiller forfatterne også spørgsmålstegn ved hvorvidt den tilgang der er i Larnaca Deklarationen spiller ind i et læringsperspektiv eller mere taler ud fra et didaktisk perspektiv. Forfatterne fremhæver også at Learning Design kan være medvirkende til at sikre og højne kvaliteten i 
en uddannelseskontekst, da det skaber rum for dialog, refleksion og facilitering af undervisningsudviklingen, men at det også har en vis sammenhæng med effektivitet.

- Theory-Generating Practice: Proposing a principle for Learning Design af Mie Buhl, der i artiklen beskriver og eksemplificerer et Learning Design, som forfatteren har opbygget erfaring med i forhold til at design uddannelsesforløb inden for universitetsundervisning. Der er fokus på de studerendes rolle som kreative aktører gennem deres læringsproces, hvilket i høj grad forbindes med 21ende århundredes kompetencer. Gennem brugen af teknologi og arbejdet med TGP som Learning Design metode sikres en større effektivitet af de læreprocesser der sættes i spil.

- Studenterproduceret video til eksamen af Kenneth Hansen og Kristian Nøhr Jensen. Artiklen kombinerer Learning Design med stilladseringsbegrebet ud fra en antagelse om at undervisere ofte har en fagfaglighed, som ikke nødvendigvis baserer sig på flere fag, hvilket skaber et behov for en øget stilladsering i en tværfaglig kontekst med multimodale afleveringsmuligheder. Dette for at skabe en vis kvalitet $\mathrm{i}$ den undervisning og evaluering/eksamen der er, men også i det produkt som de studerende for eksempel forventes at producere.

\section{Learning Design i Danmark anno 2016}

I forbindelse med udarbejdelsen af dette temanummer blev der udsendt et online spørgeskema til samtlige university colleges og universiteter i Danmark om deres praksis inden for området. Spørgeskemaet kunne frit tilgås fra 3. maj 2016, og data blev indsamlet indtil d. 14. december 2016. I alt 234 primært undervisere, forskere og undervisningsudviklere fra samtlige otte universiteter og syv university colleges deltog, hvoraf dog kun 98 gennemførte undersøgelsen. Der var en massiv overvægt af respondenter fra University College Syd (UC Syd) (66\%), Københavns Universitet (KU) (10\%) og Aarhus Universitet (AU) (8\%).

Spørgeskemaet viste, at Learning Design er et tilsyneladende velkendt koncept blandt respondenterne og hele $87 \%$ havde hørt eller læst om Learning Design, 34\% havde selv tilrettelagt undervisning vha. Learning Design og 24\% havde deltaget i undervisning tilrettelagt vha. Learning Design (Figur 1). Hvis man fraregner UC Syd, tegner der sig en nogenlunde tilsvarende spredning, hvor 77\% havde hørt eller læst om Learning Design, $56 \%$ havde selv tilrettelagt undervisning vha. Learning Design og 33\% havde deltaget i undervisning tilrettelagt vha. Learning Design. 


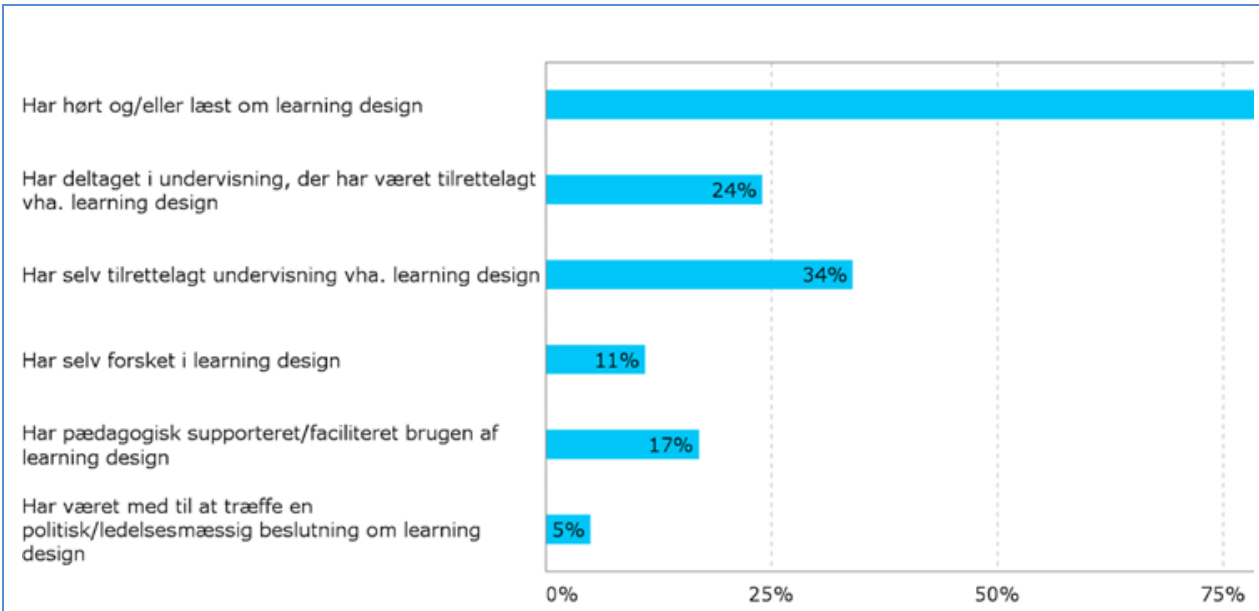

Figur 1: Erfaring med eller kendskab til Learning Design.

Respondenternes opfattelse af Learning Design var imidlertid noget bredere end den gængse opfattelse som beskrevet af Conole (2013) og fx i Larnaca Deklarationen (Dalziel et al., 2016), og eksempelvis rangerer "genbrug af designs" og "deling af designs" lavt omend de opfattes som centrale principper i tilgangen ifølge de førnævnte referencer, hvorimod "brugen af teknologi i undervisningen" er rangeret højt, selvom det ikke er essentielt for Learning Design. Man kunne således have en formodning om, at Learning Design-konceptet bliver anvendt til at beskrive forskelligartede typer af praksisser, der vedrører udvikling af undervisning - gerne med teknologi involveret mhp. at forbedre de studerendes læring — og ofte brugt som et substantiv til at referere til produktet af en designproces. 
Fokus på de studerendes læring

Brugen af pæedagogiske/didaktiske modeller for undervisningen og dens tilrettelæggelse

Brugen af teknologi i undervisningen

At undervisere står for udviklingen

Brug af it-værktøjer til at udvikle og repræsentere designs/undervisningspraksisser

En design-proces

Fokus på undervisernes pædagogiske færdigheder

Brugen af pædagogiske skabeloner for undervisningen og dens tilrettelæggelse

Brugen af strategiske modeller, initiativer og mål for undervisningen og dens tilrettelæggelse

Genbrug af designs

Brugen af såkaldte "patterns" for undervisningen og dens tilrettelæggelse

Deling af designs

At studerende er involveret i tilrettelæggelsen af undervisningen

Fokus på undervisernes tekniske færdigheder

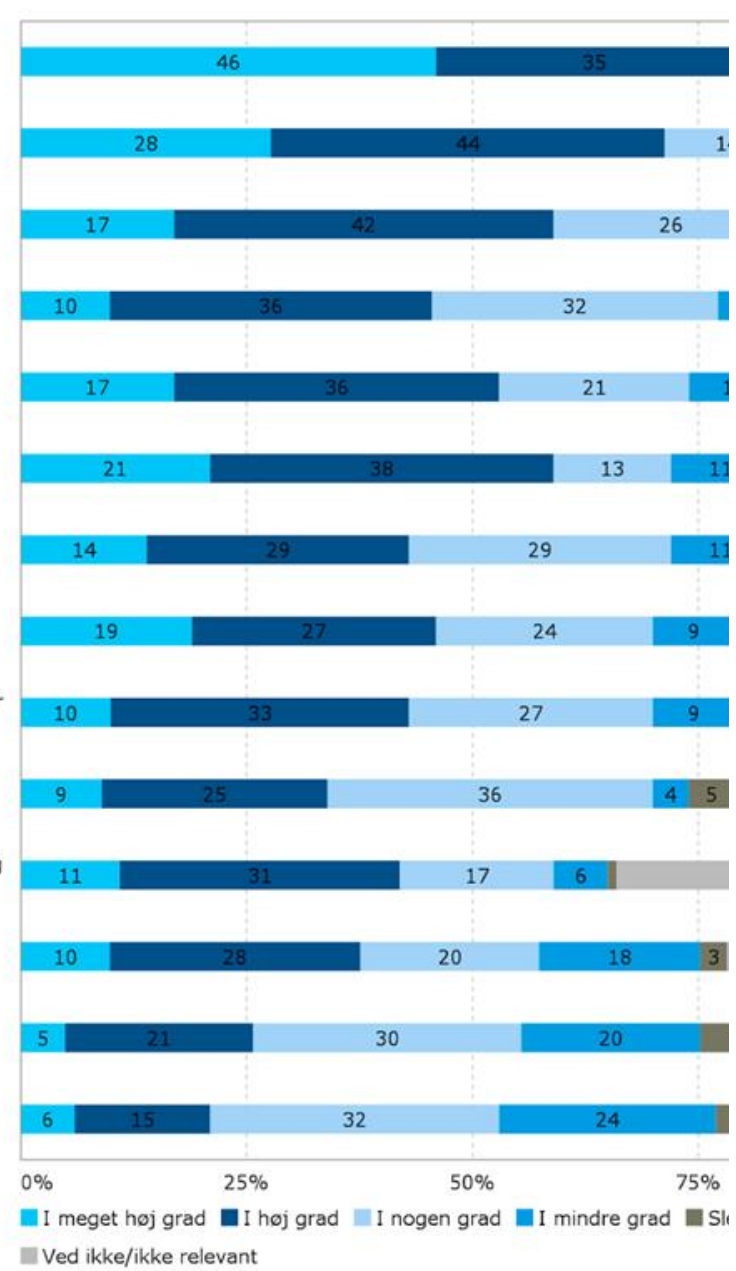

Figur 2: I hvilken grad respondenterne fandt de listede karakteristika kendetegnende for Learning Design.

Med hensyn til udbredelse af Learning Design var der kendskab blandt respondenterne til at 33\% $(n=5)$ af institutionerne, AU, KU, UC Lillebælt, UC Syd og VIA UC, havde/havde haft initiativer til udbredelse af Learning Design. Ligeledes var der kun kendskab blandt respondenterne til kurser og anden undervisning for studerende baseret på Learning Designmodeller på de selvsamme institutioner. I forhold til kurser og workshops for undervisere i Learning Design, havde respondenterne dog også kendskab til sådanne initiativer på Metropol. Dvs. 40\% af institutionerne havde kurser og workshops i Learning Design. Der kunne med andre ord identificeres en række initiativer til Learning Design ved godt en tredjedel af institutionerne, men også at der ved cirka to tredjedele af institutionerne ikke kunne identificeres hverken initiativer, kurser for undervisere eller undervisning baseret på tilgangen.

I forhold til spørgsmålet om Learning Design primært rummer et kvalitetssikringspotentiale eller et effektiviseringspotentiale fordeler 
svarene sig som vist i tabel 1 . Undersøgelsen viste at $27 \%$ af respondenterne så kvalitetssikring som det primære potentiale, mens 18\% primært så et effektiviseringspotentiale. Endvidere var der hele 55\%, der enten så lige dele kvalitetssikrings- og effektiviseringspotentiale eller svarer "ved ikke". Selv inden for respondentgruppen af undervisningsudviklere og pædagogiske konsulenter, hvor man kunne forvente det største kendskab til Learning Design, svarede hele 19\% "ved ikke" til selvsamme spørgsmål. Dette kunne tyde på en meget begrænset erfaring og/eller viden om Learning Design. Det er ligeledes interessant, at hele $27 \%$ ser et effektiviseringspotentale på trods af den ellers udbredte opfattelse af Learning Design som værende karakteriseret ved pædagogisk udvikling og fokus på de studerendes læring (se figur 2).

Tabel 1: Respondenternes syn på Learning Design i forhold til kvalitet og effektivisering.

\begin{tabular}{|c|c|c|}
\hline & Respondenter & Procent \\
\hline $\begin{array}{l}\text { Learning design-tilgangens potentiale består i langt } \\
\text { overvejende grad i muligheden for at kvalitetssikre } \\
\text { undervisningen og/eller undervisningsudviklingen }\end{array}$ & 11 & $11 \%$ \\
\hline $\begin{array}{l}\text { Learning design-tilgangens potentiale består primært i } \\
\text { muligheden for at kvalitetssikre undervisningen og/eller } \\
\text { undervisningsudviklingen og sekundært i muligheden for at } \\
\text { effektivisere undervisningen og/eller undervisningsudviklingen }\end{array}$ & 16 & $16 \%$ \\
\hline $\begin{array}{l}\text { Learning design-tilgangen rummer lige potentialer for } \\
\text { kvalitetssikring såvel som effektivisering af undervisningen og } \\
\text { undervisningsudviklingen }\end{array}$ & 29 & $30 \%$ \\
\hline $\begin{array}{l}\text { Learning design-tilgangens potentiale består primært i } \\
\text { muligheden for at effektivisere undervisningen og/eller } \\
\text { undervisningsudviklingen og sekundært i muligheden for at } \\
\text { kvalitetssikre undervisningen og/eller undervisningsudviklingen }\end{array}$ & 10 & $10 \%$ \\
\hline $\begin{array}{l}\text { Learning design-tilgangens potentiale består i langt } \\
\text { overvejende grad i muligheden for at effektivisere } \\
\text { undervisningen og/eller undervisningsudviklingen }\end{array}$ & 8 & $8 \%$ \\
\hline Ved ikke & 24 & $25 \%$ \\
\hline I alt & 98 & $100 \%$ \\
\hline
\end{tabular}

Alt i alt er det med dette temanummers otte artikler samt denne indledende undersøgelse af Learning Design i Danmark vores håb at kaste lys over og opmærksomhed på Learning Design anno 2016, og hvorledes dette kan omsættes til pædagogisk praksis med henblik på at systematisere, kvalitetssikre og/eller effektivisere brugen af teknologi i undervisningen og understøtte undervisningsudvikling. God læselyst.

\section{Referencer}

Bates, A. T. (2005). Technology, e-learning and distance education. Routledge. 
Carvalho, L., \& Goodyear, P. (Eds.). (2014). The architecture of productive learning networks. New York: Routledge/Taylor \& Francis Group.

Conole, G. (2013). Designing for Learning in an Open World. New York, NY: Springer New York.

Conole, G., Klobučar, T., Rensing, C., Konert, J., \& Lavoué, É. (Eds.). (2015). Design for Teaching and Learning in a Networked World (Vol. 9307). Cham: Springer International Publishing.

Dalziel, J., Conole, G., Wills, S., Walker, S., Bennett, S., Dobozy, E., Bower, M. (2016). The Larnaca Declaration on Learning Design: 2013. In J. Dalziel (Ed.), Learning Design: Conceptualizing a Framework for Teaching and Learning Online (1 ed., pp. 1-41). United States: Routledge.

Dohn, N. B., \& Hansen, J. J. (Eds.). (2016). Didaktik, design og digitalisering. København: Samfundslitteratur.

Laurillard, D. (2012). Teaching as a design science: building pedagogical patterns for learning and technology. New York, NY: Routledge.

Mor, Y., Mellar, H., Warburton, S., \& Winters, N. (Eds.). (2014). Practical design patterns for teaching and learning with technology. Rotterdam: Sense Publishers. 